\title{
PENGARUH MODEL PEMBELAJARAN STUDENT TEAMS ACHIEVEMENT DIVISION (STAD) DENGAN BANTUAN MEDIA LINGKUNGAN SEKITAR TERHADAP HASIL BELAJAR IPA SISWA
}

\author{
Silpiana ${ }^{1}$, dan Iwan Fitriani ${ }^{2}$ \\ Universitas Islam Negeri Mataram \\ Email: ${ }^{1}$ silfiana@uinmataram.ac.id, ${ }^{2}$ iwanfitriani@uinmataram.ac.id
}

\begin{abstract}
Abstrak: Penelitian ini bertujuan untuk mengetahui pengaruh model pembelajaran student teams achievement division (STAD) dengan bantuan media lingkungan sekitar terhadap hasil belajar IPA siswa kelas V MI Miftahul Ishlah Tembelok tahun pelajaran 2018/2019. Penelitian ini merupakan penelitian kuantitatif jenis eksperimen semu (quasi eksperimental design) dan menggunakan desain posttest-only control design. Populasi dalam penelitian ini adalah siswa kelas $\mathrm{V}$ MI Miftahul Ishlah Tembelok yang terdiri dari 2 (dua) kelas. Teknik pengumpulan data yang digunakan adalah tes dan dokumentasi. Analisis data menggunakan rumus t-test polled varians. Hasil penelitian menyimpulkan bahwa ada pengaruh yang signifikan model pembelajaran student teams achievement division (STAD) dengan bantuan media lingkungan sekitar terhadap hasil belajar IPA siswa kelas V MI Miftahul Ishlah Tembelok tahun pelajaran 2018/2019. Dari hasil perhitungan diperoleh nilai t hitung sebesar 3,2251, sedangkan nilai t-tabel pada taraf signifikasi 5\% adalah 2,0275, dengan demikian Ho ditolak dan Ha diterima.
\end{abstract}

Kata kunci: Model Pembelajaran STAD, Media Lingkungan Sekitar, Hasil Belajar IPA.

\section{PENDAHULUAN}

Proses pembelajaran merupakan inti dari sebuah proses pendidikan. Berhasil tidaknya suatu proses pendidikan yang dilaksanakan akan menentukan kualitas atau output dari peserta didik, sehingga diperlukan inovasi-inovasi yang sesuai dengan kemajuan ilmu pengetahuan dan teknologi tanpa mengabaikan nilai-nilai kemanusiaan. Pendidikan juga dapat dipahami sebagai sarana melahirkan generasi-generasi yang cerdas, kreatif, terampil, bertanggung jawab, produktif dan berbudi pekerti luhur. Sebagaimana yang tercantum dalam Undang-Undang Nomor 20 Tahun 2003 bahwa pendidikan bertujuan untuk berkembangnya potensi peserta didik agar menjadi manusia yang beriman dan bertakwa kepada Tuhan yang Maha Esa, berakhlak mulia, sehat, berilmu, cakap, kreatif, mandiri, dan menjadi warga negara yang demokratis serta bertanggung jawab. ${ }^{1}$

Dalam dunia pendidikan, guru merupakan pemandu yang sangat berperan penting dalam keberlangsungan proses belajar mengajar. Tercapai atau tidaknya materi pembelajaran yang diajarkan tergantung kepada bagaimana kemampuan guru dalam

${ }^{1}$ Undang-Undang Republik Indonesia Nomor 20 Tahun 2003 Tentang Sistem Pendidikan Nasional. 
menguasai materi, serta seberapa terampil guru dalam memilih model dan media yang akan digunakan dalam membelajarkan peserta didik. Ketercapaian tujuan suatu pendidikan dapat diketahui dalam proses belajar dari sejauh mana peserta didik dapat memahami pelajaran yang disampaikan oleh seorang guru. Sebagaimana dijelaskan oleh Jamaludin bahwa belajar merupakan suatu proses yang dialami seseorang melalui kegiatan yang dilakukannya untuk mencapai tujuan tertentu, sehingga dimungkinkan terjadinya perubahan dalam pengetahuannya, sikapnya, keterampilannya, kebiasaannya, pengalamannya, minatnya, penghargaan, dan penyesuaian dirinya. ${ }^{2}$

Oleh sebab itu, tanggung jawab keberhasilan pendidikan dalam proses belajarnya berada di tangan guru. Untuk itu, guru sebagai fasilitator dalam proses pembelajaran harus dapat mengelola kegiatan belajar mengajar dengan menciptakan pembelajaran yang bermakna sesuai dengan kondisi dan kemampuan peserta didik, serta mampu menerapkan model dan menggunakan media yang sesuai materi yang diinteraksikan dengan siswa. Adapun di antara yang menjadi faktor rendahnya hasil belajar peserta didik serta kurangnya kemampuan peserta didik untuk bisa memahami apa yang disampaikan oleh gurunya antara lain kurangnya pengetahuan guru tentang model serta media yang dapat digunakan dalam proses pembelajaran khususnya pada materi IPA.

Berdasarkan hasil observasi yang telah dilakukan di MI Miftahul Ishlah Tembelok pada siswa kelas V, dapat diketahui bahwa kemampuan siswa dalam memahami materi IPA yang disampaikan oleh guru terbilang masih sangat kurang. Hanya siswa yang memiliki prestasi tinggi yang dapat mengerti dan memahami apa yang diajarkan oleh gurunya, sementara siswa yang lain hanya mendengarkan apa yang disampaikan oleh gurunya dan sulit bagi mereka untuk bisa mengerti dan memahami pelajaran yang didapatkannya. Hal ini dikarenakan strategi guru dalam memilih model pembelajaran masih kurang tepat, serta tidak adanya inovasi dari seorang guru untuk menghadirkan media secara langsung yang dapat mendukung keberhasilan proses belajar mengajar. Dalam proses pembelajaran guru belum menerapkan model pembelajaran yang variatif yang dapat menstimulus peserta didik dalam proses belajarnya. Hal ini dapat dilihat dari nilai hasil Ujian Tengah Semester (UTS) Semester Ganjil Tahun Pelajaran 2017/2018 pada siswa kelas VMI Miftahul Ishlah 
Tembelok, dari hasil nilai UTS dapat dilihat masih ada siswa yang mendapat nilai di bawah kriteria ketuntasan minimal (KKM) yaitu 70.3 Persoalan yang sudah dipaparkan didukung dengan data hasil belajar yang didapat oleh siswa. Dari hasil nilai ujian tengah semester (UTS) semester ganjil tahun pelajaran 2017/2018, dapat diketahui bahwa dari kelas A dengan jumlah siswa 23 orang didapatkan presentase siswa yang nilainya di atas KKM adalah 60\% dan di bawah KKM 40\% siswa. Sementara dari kelas B dengan jumlah siswa 16 orang, diketahui presentase siswa yang nilainya di atas KKM adalah 50\% dan di bawah KKM $50 \%$ siswa. $^{4}$

Beberapa masalah yang dipaparkan di atas, ditentukan oleh beberapa faktor, seperti halnya model dan media pembelajaran. Di mana pemilihan model dan media yang tepat sangat berpengaruh dalam meningkatkan minat belajar dan hasil belajar siswa. Dalam suatu proses belajar mengajar, dua unsur ini sangat penting dan saling berkaitan. Pemilihan salah satu model pembelajaran tertentu akan mempengaruhi jenis media pembelajaran apa yang sesuai yang akan digunakan. Di samping itu, ada berbagai aspek lain yang harus diperhatikan dalam memilih media, antara lain tujuan pengajaran, jenis tugas, dan respon yang diharapkan dari peserta didik untuk bisa dikuasai setelah pengajaran berlangsung, dan konteks pembelajaran termasuk karakteristik siswa.

Salah satu model pembelajaran yang dapat dijadikan alternatif bagi guru dalam proses pembelajaran IPA adalah model pembelajaran kooperatif tipe STAD. Menurut Eggen and Kauchak sebagaimana dikutip oleh Trianto, pembelajaran kooperatif merupakan sebuah kelompok strategi pengajaran yang melibatkan siswa bekerja secara berkolaborasi untuk mencapai tujuan bersama. ${ }^{5}$ Pembelajaran kooperatif bukanlah sesuatu yang baru dalam proses pembelajaran. Dalam kelompok-kelompok yang terdiri dari 4-5 orang untuk bekerja sama dalam menguasai materi yang diberikan oleh guru. Setiap kelompok memiliki tanggung jawab yang sama untuk keberhasilan kelompoknya. Tujuan dibentuknya kelompok tersebut adalah untuk memberikan kesempatan kepada semua siswa agar dapat

${ }^{3}$ Hasil Dokumentasi dan Observasi Proses Pembelajaran Kelas V MI Miftahul Ishlah Tembelok, 27 September-20 November 2019.

${ }^{4}$ Wawancara dan Dokumentasi dengan Guru Kelas V, MI Miftahul Ishlah Tembelok, 29 Februari 2019.

${ }^{5}$ Trianto. 2009. Mendesain Model Pembelajaran Inovatif-Progresif. Jakarta: Kencana Prenada Media Group. hal. 58. 
terlibat secara aktif dalam proses berpikir dan kegiatan belajarnya. Sedangkan student teams achievement division (STAD) merupakan salah satu tipe dari model pembelajaran kooperatif dengan menggunakan kelompok kecil. Dalam metode ini, pembelajaran diawali dengan penyampaian tujuan pembelajaran, penyampaian materi, kegiatan kelompok, kuis, dan penghargaan kelompok. ${ }^{6}$

Pembelajaran dengan model kooperatif tipe STAD ini diharapkan mampu mendorong peserta didik untuk berpikir kritis dan berani mengungkapkan gagasannya dalam suatu kelompok belajar agar tercapai hasil belajar yang lebih maksimal. Student teams achievement division (STAD) sebagaimana yang dimaksudkan dalam penelitian ini, berorientasi pada terciptanya kondisi belajar yang dapat meningkatkan hasil belajar yakni dengan cara memacu siswa untuk bisa saling mendorong dan membantu satu sama lain untuk menguasai keterampilan yang diajarkan guru. ${ }^{7}$ Dalam pembelajaran ini diharapkan peserta didik secara berkelompok dapat menemukan suatu fakta dari suatu konsep yang telah dipelajari dalam materi perubahan lingkungan. Untuk meningkatkan keaktifan peserta didik dalam proses belajar, maka guru harus memahami tentang model dan media pembelajaran yang efektif yang dapat membantu siswa agar dapat belajar secara optimal.

Berdasarkan uraian di atas perlu dikembangkan suatu model pembelajaran, yang dapat meningkatkan hasil belajar peserta didik dalam memahami materi tentang perubahan lingkungan yang terjadi di sekitar yang didukung dengan penggunaan media lingkungan sekitar. Penelitian ini bertujuan untuk mengetahui pengaruh model pembelajaran kooperatif tipe Student Teams Achievement Division (STAD) dengan bantuan media lingkungan sekitar terhadap hasil belajar IPA siswa kelas V MI Miftahul Ishlah Tembelok Tahun Pelajaran 2018/2019.

${ }^{6}$ Trianto Ibnu Badar al-Tabany. 2015. Mendesain Model Pembelajaran Inovatif, Progresif, dan Kontekstual. Jakarta: Prenadamedia Group, 2015), hal. 118.

${ }^{7}$ Rusman. 2017 Belajar dan Pembelajaran Berorientasi Standar Proses Pendidikan. Jakarta: Kencana, hal. 305.

136 Copyright (c) el-Midad : Jurnal PGMI 2019 


\section{LANDASAN TEORI}

\section{A. Tinjauan Tentang Model Pembelajaran Kooperatif Tipe STAD}

\section{Pengertian model pembelajaran kooperatif}

Model pembelajaran kooperatif (cooperative learning) merupakan suatu model pembelajaran yang dapat meningkatkan pencapaian akademik dan sikap sosial peserta didik melalui kerja sama di antara mereka". ${ }^{8}$ Dalam model pembelajaran kooperatif ini guru berperan sebagai fasilitator yang berfungsi sebagai jembatan penghubung ke arah pemahaman yang lebih tinggi. Pembelajaran kooperatif (cooperative learning) merupakan suatu bentuk pembelajaran di mana siswa belajar dan bekerja dalam suatu kelompok kecil secara kolaboratif yang anggota kelompoknya terdiri dari 4-6 orang dengan struktur anggota kelompok yang bersifat heterogen.

Pelaksanaan model pembelajaran kooperatif membutuhkan partisipasi dan kerjasama dalam kelompok pembelajaran. Pembelajaran kooperatif atau yang disebut dengan cooperative learning dapat meningkatkan cara belajar peserta didik menuju belajar yang lebih baik, sikap tolong menolong dalam beberapa perilaku peserta didik. Belajar kooperatif menekankan pada tujuan dan kesuksesan kelompok, yang hanya dapat dicapai jika semua anggota kelompok dapat mencapai tujuan pembelajaran melalui penguasaan materi. ${ }^{9}$

Dari beberapa tinjauan tentang pembelajaran kooperatif di atas, maka dapat disimpulkan bahwa pada dasarnya tujuan dari model pembelajaran kooperatif ini setidaktidaknya untuk mencapai beberapa tujuan diantaranya: (1) Memperbaiki prestasi belajar siswa dan membantu siswa untuk menyelesaikan tugas-tugas akademik secara berkelompok; (2) Memberi peluang bagi siswa dari berbagai latar belakang dan kondisi untuk bekerja dengan saling bergantung secara positif dan menghargai satu sama lainnya; (3) Mengajarkan kepada siswa keterampilan-keterampilan bekerjasama dan berkolaborasi untuk mencapai keterampilan sosial yang penting dimiliki oleh masing-masing siswa.

Dalam pembelajaran kooperatif terdapat beberapa prosedur atau langkah-langkah dalam pembelajarannya yang pada prinsipnya terdiri atas empat tahap, yaitu: (1) Penjelasan

\footnotetext{
${ }^{8}$ Asih Widi Wisudawati Dan Eka Sulistyowati. 2015. Metodologi Pembelajaran IPA. Jakarta: PT Bumi Aksara. 53.

9Trianto Ibnu Badar al-Tabany. 2015. Mendesain Model Pembelajaran Inovatif, Progresif, dan Kontekstual. Jakarta: Prenadamedia Group. hal. 109.
} 
materi; (2) Belajar dalam kelompok; (3) Penilaian; dan (4) Pengakuan kelompok ${ }^{10}$. Adapun model pembelajaran kooperatif memilki beberapa variasi jenis model pembelajaran, walaupun prinsip dasar dari pembelajaran kooperatif ini tidak berubah. Jenis-jenis model pembelajaran kooperatif tersebut sebagai berikut: (1) Model Student Teams Achievement Division (STAD).; (2) Model Jigsaw (Tim Ahli); (3) Model Group Investigation (Investigasi Kelompokk); (4) Model Make A Match (Membuat Pasangan).

\section{Model Pembelajaran Kooperatif Tipe STAD}

Student teams achievement division (STAD) merupakan salah satu tipe dari model pembelajaran kooperatif dengan menggunakan kelompok kecil, dimana jumlah anggota dari setiap kelompok terdiri dari 4-5 orang peserta didik secara heterogen. Dalam model kooperatif tipe STAD ini pembelajaran diawali dengan penyampaian tujuan pembelajaran, penyampaian materi, kegiatan kelompok, kuis, dan penghargaan kelompok. ${ }^{11}$

Lebih jauh Slavin dalam Rusman memaparkan bahwa: "gagasan utama di belakang STAD adalah memacu siswa untuk bisa saling mendorong dan membantu satu sama lain untuk menguasai keterampilan yang diajarkan guru."12 Jika setiap kelompok menginginkan kelompok mereka agar memperoleh hadiah, maka mereka harus saling membantu antar teman sesama kelompok mereka dalam mempelajari pelajaran yang disampaikan oleh guru. Setiap peserta didik dalam kelompoknya harus mampu saling mendorong teman kelompoknya untuk melakukan yang terbaik, memperhatikan norma-norma bahwa belajar itu penting, berharga, dan menyenangkan. Dalam proses pembelajaran, setiap peserta didik diberi waktu untuk bekerja sama setelah pelajaran diberikan oleh guru, tetapi tidak boleh saling membantu ketika menjalani kuis, sehingga setiap siswa harus bisa menguasai materi dengan baik karena merupakan tanggung jawab perseorangan.

\section{Langkah-langkah model pembelajaran kooperatif tipe STAD}

Langkah-langkah pembelajaran kooperatif tipe STAD ini didasarkan pada langkahlangkah pembelajaarn kooperatif yang diantaranya adalah: (1) Penyampaian tujuan dan

10Jumanta Hamdayama, Model dan Metode Pembelajaran Kreatif dan Berkarakter, (Bogor: Ghalia Indonesia, 2014), hlm. 65-66.

${ }^{11}$ Trianto Ibnu Badar al-Tabany, Mendesain Model ..., hlm. 118.

${ }^{12}$ Rusman, Belajar dan Pembelajaran ..., hlm. 305. 
motivasi; (2) Pembagian kelompok; (3) Presentasi dari guru; (4) Kegiatan belajar dalam tim (kerja tim); (5) Kuis (evaluasi); dan (6) Penghargaan prestasi tim ${ }^{13}$.

Adapun kelebihan metode STAD antara lain sebagai berikut: (1) Siswa bekerja sama dalam mencapai tujuan dengan menjunjung tinggi norma-norma kelompok; (2) Siswa aktif membantu dan memotivasi semangat untuk berhasil bersama; (3) Aktif berperan sebagai tutor sebaya untuk lebih meningkatkan keberhasilan kelompok; (4) Interaksi antarsiswa seiring dengan peningkatan kemampuan mereka dalam berpendapat; (5) Meningkatkan kecakapan individu; (6) Meningkatkan kecakapan kelompok; (7) Tidak bersifat kompetitif dan; (8) Tidak memiliki rasa dendam. Sedangkan kekurangan Metode Pembelajaran STAD; (1) Konstribusi dari siswa berprestasi rendah menjadi kurang; (2) Siswa berprestasi tinggi akan mengarah kepada kekecewaan karena peran anggota yang pandai lebih dominan; (3) Membutuhkan waktu yang lebih lama untuk siswa sehingga sulit untuk mencapai target kurikulum; (4) Membutuhkan waktu yang lebih lama untuk guru sehingga pada umumnya guru tidak mau menggunakan pembelajaran kooperatif; (5) Membutuhkan kemampuan khusus guru sehingga tidak semua guru dapat melakukan pembelajaran kooperatif; dan (6) Menurut sifat tertentu dari siswa, misalnya sifat suka bekerja sama.

\section{B. Tinjauan Tentang Media Lingkungan Sekitar}

\section{Pengertian media pembelajaran}

Pada hakikatnya kegiatan belajar mengajar adalah suatu bentuk komunikasi (proses penyampaian pesan). Proses komunikasi harus diwujudkan melalui kegiatan penyampaian dan tukar menukar pesan atau informasi oleh setiap guru kepada peserta didik. Agar tidak terjadi kesesatan dalam proses komunikasi perlu digunakan sarana yang dapat membantu dan mempermudah proses komunikasi yang salah satunya disebut dengan media.

Kata media berasal dari bahasa latin dan merupakan bentuk jamak dari kata medium yang secara harfiah berarti perantara atau pengantar. Medoe adalah perantara atau pengantar pesan dari pengirim ke penerima pesan. ${ }^{14}$ Pupuh Fathurrohman dan M. Sobry Sutikno dalam bukunya mengatakan bahwa media apabila dipahami secara garis besar adalah manusia, materi atau kejadian yang membangun suatu kondisi yang membuat siswa mampu

\footnotetext{
${ }^{13}$ Rusman, Belajar dan Pembelajaran ..., hlm. 306-307.

${ }^{14}$ Arief S. Sadiman, dkk., Media Pendidik.an ..., hlm. 6.
} 
memperoleh pengetahuan, keterampilan atau sikap. ${ }^{15}$ Dalam aktivitas pembelajaran, media dapat didefinisikan sebagai sesuatu yang dapat membawa informasi dan pengetahuan dalam interaksi yang berlangsung antara pendidik dan peserta didik. Dengan demikian dapat disimpulkan bahwa media pembelajaran adalah segala jenis komponen yang ada dalam lingkungan siswa yang dapat digunakan untuk menyampaikan pesan atau informasi kepada peserta didik yang dapat merangsang siswa untuk belajar.

\section{Lingkungan sebagai media pembelajaran}

Lingkungan pendidikan adalah segala sesuatu yang ada di sekitar manusia, baik itu berupa benda mati, makhluk hidup, ataupun peristiwa-peristiwa yang terjadi termasuk kondisi masyarakat terutama yang dapat memberikan pengaruh kuat kepada individu. Seperti lingkungan tempat pendidikan berlangsung dan lingkungan tempat anak bergaul serta benda-benda yang ada di lingkungan sekitar. ${ }^{16}$ Secara harfiah menurut Kamus Besar Bahasa Indonesia yang dikutip dari Rita Maryani dkk, "lingkungan diartikan sebagai suatu tempat yang memengaruhi pertumbuhan manusia, sedangkan menurut kamus bahasa inggris environment diartikan sebagai "sesuatu yang berhubungan dengan lingkungan atau suasana"17. Jika digabungkan dari pengertian istilah lingkungan dari kedua bahasa tersebut, maka lingkungan dapat diartikan sebagai suatu tempat atau suasana (keadaan) yang dapat memengaruhi pertumbuhan dan perkembangan seseorang.

Berdasarkan pengertian dari media dan lingkungan sekitar seperti yang telah dijelaskan di atas, maka dapat ditarik kesimpulan bahwa pengertian media lingkungan adalah segala bentuk penyampaian pesan atau informasi dalam proses pembelajaran dengan cara melibatkan dan berinteraksi langsung antara peserta didik dengan segala yang ada dalam lingkungan tersebut.

\section{Fungsi lingkungan sebagai media pembelajaran}

Dalam suatu proses pembelajaran, lingkungan memiliki peranan yang sangat penting karena lingkungan bisa dijadikan sebagai salah satu sumber atau media dalam proses belajar

${ }^{15}$ Pupuh Fathurrohman dan M. Sobry Sutikno, Strategi Belajar Mengajar..., hlm. 65.

${ }_{16}$ Abdul Kadir, Endri Yulianto, dkk., Dasar-Dasar Pendidikan ..., hlm. 157.

${ }^{17}$ Rita Maryana, Ali Nugraha \& Yeni Rachmawati. 2009. Pengelolaan Lingkungan Belajar. Jakarta: Kencana, 2009. hal. 16. 
yang dapat merangsang peserta didik dalam proses pembelajaran. Suatu lingkungan pendidikan/pengajaran memiliki fungsi-fungsi sebagai berikut:18

a) Fungsi psikologis; stimulus bersumber/berasal dari lingkungan yangmerupakan rangsangan terhadap individu sehingga terjadi respons, yang menunjukkan tingkah laku tertentu. Respons tersebut pada gilirannya dapat menjadi suatu stimulus baru yang menimbulkan respons baru, demikian seterusnya. Ini berarti menunjukkan bahwa lingkungan mengandung makna serta melaksanakan fungsi psikologis tertentu.

b) Fungsi pedagogis; lingkungan dapat memberikan pengaruh-pengaruh yang bersifat mendidik, khususnya lingkungan yang sengaja atau secara khusus disiapkan sebagai suatu lembaga pendidikan.

c) Fungsi instruksional; program instruksional merupakan suatu lingkungan pengajaran/pembelajaran yang dirancang secara khusus oleh seorang pendidik. Guru yang mengajar, materi pelajaran, sarana dan prasarana pengajaran, dan kondisi lingkungan kelas (fisik) merupakan lingkungan yang sengaja dikembangkan untuk mengembangkan tingkah laku peserta didik atau merangsangnya untuk bisa belajar aktif dalam proses pembelajaran.

\section{Langkah-langkah pembelajaran dalam memanfaatkan media lingkungan sekitar}

Menggunakan lingkungan sebagai media dan sumber tentu memerlukan persiapan dan perencanaan yang matang. Tanpa adanya suatu perencaanaan yang matang kegiatan belajar mengajar bisa tidak terkendali, yang dapat menyebabkan tujuan pembelajaran tidak bisa tercapai. Untuk itu ada beberapa langkah pembelajaran yang harus ditempuh dalam pemanfaatan media di lingkungan sekitar, yakni: langkah persiapan, pelaksanaan, dan tindak lanjut. ${ }^{19}$

18Oemar Hamalik, Proses Belajar ..., hlm. 196.

${ }^{19}$ Nana Sudjana dan Ahmad Rivai, Media Pembelajaran ..., hlm. 214-217. 
a) Langkah persiapan

Ada beberapa hal yang perlu diperhatikan dalam langkah persiapan, antara lain:

1) Dalam hubungannya dengan pembahasan bidang studi tertentu, guru menentukan tujuan belajar yang diharapkan bisa diperoleh peserta didik yang berkaitan dengan penggunaan media lingkungan sekitar sebagai sumber belajar.

2) Tentukan objek yang harus dipelajari. Dalam menetapkan objek yang akan dijadikan sebagai media dan sumber belajar hendaknya diperhatikan relevansi dengan tujuan belajar, kemudahan dalam menjangkaunya dan tersedianya sumber belajar yang akan dipelajari oleh peserta didik.

3) Menentukan cara belajar peserta didik. Misalnya dengan mengamati suatu proses, dan melakukan percobaan terkait dengan apa yang akan dipelajari atau yang sedang dipelajari.

b) Langkah pelaksanaan

Pada tahap ini adalah melakukan kegiatan belajar yang telah disusun sesuai dengan rencana yang telah dipersiapkan. Biasanya kegiatan belajar akan diawali dengan penjelasan guru mengenai objek yang akan dipelajari dan diteliti sesuai dengan tujuan pembelajaran yang hendak akan dicapai. Dalam penjelasan tersebut,peserta didik bisa mengajukan pertanyaan terkait dengan materi yang diajarkan oleh seorang guru mengenai hal-hal yang belum dipahami. Setelah informasi diberikan oleh seorang guru, berikutnya akan dilaksanakan percobaan (eksperimen) terkait penggunaan media di lingkungan sekitar.

c) Tindak lanjut

Tindak lanjut dari kegiatan ini adalah, setiap siswa diminta untuk menulis dan menyimpulkan sendiri apa yang didapatkannya pada hari itu terkait dengan pembelajaran IPA mengenai perubahan lingkungan dengan menggunakan media lingkungan sekitar. Di samping menyimpulkan isi pembelajaran pada hari itu, guru juga memberikan penilaian terhadap kegiatan belajar dan hasil belajar pesera didik dengan memberikan tes atau soal kepada peserta didik. 


\section{Tinjauan Tentang Hasil Belajar}

\section{Pengertian hasil belajar}

Hasil belajar adalah penguasaan pengetahuan atau keterampilan yang dikembangkan oleh mata pelajaran, yang biasanya ditunjukkan dengan nilai tes atau angka yang diberikan oleh guru. ${ }^{20}$ Hasil belajar dapat berupa perubahan dalam kemampuan kognitif, afektif dan psikomotorik, tergantung dari tujuan pembelajarannya. ${ }^{21}$ Secara sederhana, yang dimaksud dengan hasil belajar adalah kemampuan yang diperoleh seseorang setelah melalui suatu proses dalam kegiatan belajarnya. Karena pada dasarnya belajar merupakan suatu proses dari seseorang yang berusaha untuk memperoleh suatu bentuk perubahan perilaku yang relatif menetap. ${ }^{22}$

Penilaian hasil belajar oleh pendidik adalah proses pengumpulan informasi/bukti tentang capaian pembelajaran peserta didik dalam kompetensi sikap spiritual dan sikap sosial, kompetensi pengetahuan, dan kompetensi keterampilan yang dilakukan secara terencana dan sistematis, selama dan setelah proses pembelajaran ${ }^{23}$. Dalam suatu proses pembelajaran, penilaian hasil belajar menjadi sesuatu yang sangat penting, karena dengan melakukan proses penilaian hasil belajar, seorang guru akan dapat mengetahui sejauh mana tingkat keberhasilannya dalam menerapkan suatu model atau penggunaan media dalam proses pembelajarannya.

\section{Faktor-faktor yang mempengaruhi hasil belajar}

Berhasil atau tidaknya seseorang dalam belajar disebabkan beberapa faktor yang mempengaruhi pencapaian hasil belajar yaitu yang berasal dari dalam peserta didik yang belajar (faktor internal) dan ada pula yang berasal dari luar peserta didik yang belajar (faktor eksternal). Menurut Slameto, faktor-faktor yang mempengaruhi hasil belajar peserta didik yaitu: ${ }^{24}$ faktor internal terdiri dari: faktor jasmaniah, faktor psikologis dan faktor eksternal terdiri dari: faktor keluarga, faktor sekolah, dan faktor masyarakat. Sedangkan menurut

20Sri Giarti, 2012. "Penerapan Model Pembelajaran Assure Untuk Meningkatkan Hasil Belajar IPA Siswa Kelas VI SD Negeri 2 Bengle Kecamatan Wonosegero - Boyolali“, Sholaria, Vol. 2, Nomor 1, Januari 2012, hal. 201.

${ }^{21}$ Purwanto. 2014. Evaluasi Hasil Belajar. Yogyakarta: Pustaka Pelajar, 2014. hal. 44.

22Ahmad Susanto. 2016. Teori Belajar dan Pembelajaran di Sekolah Dasar. Jakarta: Kencana. hal. 5.

23Permendikbud Nomor 104 Tahun 2014 Tentang Penilaian Hasil Belajar Oleh Pendidik Pada Pendidikan Dasar dan Pendidikan Menengah.

${ }^{24}$ Slameto, Belajar dan Faktor-Faktor yang Mempengaruhinya, (Jakarta: Rineka Cipta, 2003), hlm. 3. 
Muhibbin Syah, faktor utama yang mempengaruhi hasil belajar siswa antara lain: ${ }^{25}$ faktor internal yakni keadaan/kondisi jasmani dan rohani peserta didik, aktor eksternal (faktor dari luar siswa), yakni kondisi lingkungan di sekitar peserta didik misalnya faktor lingkungan, dan faktor pendekatan belajar, yakni jenis upaya belajar siswa yang meliputi strategi dan metode yang digunakan untuk melakukan kegiatan mempelajari materi-materi pembelajaran.

\section{D.Tinjauan Tentang IPA di SD/MI}

Secara etimologi, Fischer menyatakan sains berasal dari bahasa latin, yaitu scientia yang artinya secara sederhana adalah pengetahuan (knowledge). Kata sains mungkin juga berasal dari bahasa jerman, yaitu wissenchaft yang artinya sistematis, pengetahuan yang terorganisasi. Sains diartikan sebagi pengetahuan yang secara sistematis tersusun (assembled) dan bersamasama dalam suatu urutan terorganisasi. ${ }^{26}$

Sains (IPA) berkaitan dengan cara mencari tahu tentang alam secara sistematis, sehingga sains (IPA) bukan hanya penguasaan kumpulan pengetahuan yang berupa faktafakta, konsep-konsep, atau prinsip-prinsip saja, tetapi juga merupakan proses penemuan. Proses pembelajarannya menekankan pada pemberian pengalaman langsung untuk mengembangkan kompetensi agar menjelajahi dan memahami alam sekitar secara ilmiah. ${ }^{27}$ Sains (IPA) merupakan pengetahuan ilmiah, yaitu pengetahuan yang telah mengalami uji kebenaran melalui metode ilmiah, dengan ciri: objektif, metodik, sistematis, universal, dan tentatif.

Dari beberapa pengertian tentang Ilmu Pengetahuan Alam (IPA) di atas, dapat disimpulkan bahwa pembelajaran IPA adalah suatu pembelajaran yang sistematis dan terstruktur yang bukan hanya penguasaan kumpulan pengetahuan yang berupa fakta-fakta, konsep-konsep, atau prinsip-prinsip saja, tetapi juga merupakan proses penemuan. Selain itu IPA juga didefinisikan sebagai pengetahuan yang sistematis dan tersusun secara teratur, berlaku umum (universal), dan berupa data hasil observasi dan eksperimen. ${ }^{28}$

${ }^{25}$ Muhibbin Syah, Psikologi Belajar (Jakarta: Bumi Aksara, 2011), hlm. 144.

26Yusuf. 2015. Strategi Pembelajaran Biologi, Mataram: Institut Agama Islam Negeri (IAIN) Mataram. hal. 16.

27Bahtiar, 2015. Strategi Belajar Mengajar Sains (IPA), (Mataram: Institut Agama Islam Negeri (IAIN) Mataram. hal. 6.

${ }^{28}$ Asih Widi Wisudawati dan Eka Sulistyowati, Metodologi Pembelajaran..., hlm. 24.

144 Copyright (C el-Midad : Jurnal PGMI 2019 
Adapun ruang lingkup bahan kajian IPA di SD/MI menurut Kemendiknas meliputi aspek-aspek: (1) Makhluk hidup dan proses kehidupan, yaitu manusia, hewan, tumbuhan, dan interaksinya dengan lingkungan, serta kesehatan.; (2) Benda/materi, sifat-sifat dan kegunaannya meliputi: cair, padat dan gas; (3) Energi dan perubahannya meliputi: gaya, bunyi, panas, magnet, listrik, cahaya dan pesawat sederhana, dan (4) Bumi dan alam semesta meliputi: tata surya, dan benda-benda langit lainnya. ${ }^{29}$

\section{METODE PENELITIAN}

Penelitian ini merupakan penelitian kuantitatif dengan jenis kuasi eksperimen. Populasi dalam penelitian ini adalah siswa kelas V MI Miftahul Ishlah Tembelok Tahun Pelajaran 2018/2019, terdiri dari 39 siswa yang terbagi menjadi 2 kelas yaitu kelas A dengan jumlah 23 siswa dan kelas B dengan jumlah 16 siswa. Adapun desain dalam penelitian ini menggunakan jenis posttest-only control design. Design ini terdapat dua kelompok yang masingmasing dipilih secara random (R). Kelompok pertama diberi perlakuan (kelompok eksperimen) dan kelompok yang lain tidak (kelompok kontrol). Instrumen yang digunakan berupa tes hasil belajar, terdiri dari 16 soal pilihan ganda dan telah melalui proses validasi ahli, uji validitas, reliabilitas, tingkat kesukaran, daya pembeda dan keberfungsian pengecoh. Instrumen diberikan dua kali, dalam bentuk pretest dan posttest, baik pada kelompok eksperimen maupun kelompok kontrol. Teknik analisis yang digunakan adalah uji t polled varians, yang diawali dengan uji persyaratan, yaitu uji normalitas dan uji homogenitas.

\section{HASIL PENELITIAN DAN PEMBAHASAN}

\section{Hasil Penelitian}

Berdasarkan hasil penelitian yang telah dilakukan di MI Miftahul Ishlah Tembelok, diketahui nilai rata-rata hasil belajar IPA untuk kelas eksperimen adalah 75,52 dengan perolehan nilai tertinggi adalah 93 dan nilai terendah adalah 50. Dari 23 jumlah siswa pada kelas eksperimen didapatkan 16 siswa dengan kategori tuntas dan 7 siswa dengan kategori belum tuntas dari Kriteria Ketuntasan Minimum (KKM) mata pelajaran IPA sebesar 70. Adapun nilai rata-rata hasil belajar IPA untuk kelas kontrol adalah 63,87 dengan perolehan

\footnotetext{
${ }^{29}$ Ibid.
} 
nilai tertinggi adalah 87 dan nilai terendah adalah 43. Dari 16 jumlah siswa pada kelas eksperimen didapatkan 5 siswa dengan kategori tuntas dan 11 siswa dengan kategori belum tuntas dari Kriteria Ketuntasan Minimum (KKM) mata pelajaran IPA sebesar 70.

Selanjutnya dilakukan uji persyaratan, yang pertama uji normalitas dengan menggunakan rumus chi kuadrat. ${ }^{30}$ Berdasarkan hasil penghitungan uji normalitas yang pada kelas eksperimen, didapat nilai untuk $X^{2}{ }_{h t}=4,23$ dan $X^{2}{ }_{t}=5,99$. Untuk kelas kontrol didapat $X_{h t 1}^{2}=1,06$ dan $X_{{ }_{t 1}}^{2}=5,99$. Dengan demikian dapat disimpulkan bahwa $X_{\text {hit }}^{2} \quad X_{t_{1}}^{2}$, yaitu 4,23<5,99 yang artinya data hasil belajar kelas eksperimen berdistribusi normal dan 1,06<5,99 yang artinya data hasil belajar kelas eksperimen berdistribusi normal. Kedua, uji homogenitas. Hasil analisis $\mathrm{F}_{\text {bitung }}<\mathrm{F}$ tabel, yaitu 1,039<2,29 sehingga dapat dikatakan kedua kelas tersebut homogen dengan taraf signifikansi $5 \%$.

Setelah kedua persyaratan terpenuhi yaitu data terdistribusi normal dan homogen, dilakukan uji hipotesis dengan menggunakan rumus uji t sampel berpasangan. Berdasarkan penghitungan diperoleh thitung 3,2250 dan tabel 2,0273 pada taraf signifikasi 5\%. Adapun deskripsi data hasil penelitian dapat dilihat pada tabel di bawah ini.

Tabel 1. Deskripsi Data Hasil Belajar Kelas Eksperimen dan Kelas Kontrol

\begin{tabular}{|c|c|c|c|}
\hline No & Item & Kelas Eksperimen & Kelas Kontrol \\
\hline 1 & $\mathrm{~N}$ & 23 & 16 \\
\hline 2 & Nilai Tertinggi & 93 & 87 \\
\hline 3 & Nilai Terendah & 50 & 43 \\
\hline 4 & $\overline{\boldsymbol{x}}$ & 75,52174 & 63,875 \\
\hline 5 & $\mathrm{~S}$ & 11,17789 & 10,96514 \\
\hline 6 & $S^{2}$ & 124,9452249 & 120,2342952 \\
\hline \multicolumn{2}{|c|}{ Taraf signifikan } & \multicolumn{2}{|c|}{$5 \%$} \\
\hline \multicolumn{2}{|c|}{$\boldsymbol{t}_{\boldsymbol{n}}$} & $\mathbf{3 , 2 2 5 0}$ \\
\hline \multicolumn{2}{|c|}{$\boldsymbol{t}_{\boldsymbol{t}_{\mathbf{1}}}$} & $\mathbf{2 , 0 2 7 3}$ \\
\hline
\end{tabular}

${ }^{30}$ Subana, dke.., Statistik Pendidikan ..., hlm. 124. 
Penarikan kesimpulannya sebagai berikut:

a. Jika $\mathrm{t}_{\text {bitung }} \leq \mathrm{t}_{\text {tabel }}$ maka $\mathrm{H}_{0}$ diterima dan $\mathrm{H}_{\mathrm{a}}$ ditolak, artinya tidak ada pengaruh model pembelajaran kooperatif tipe STAD dengan bantuan media lingkungan sekitar terhadap hasil belajar IPA siswa kelas V MI Miftahul Ishlah Tembelok.

b. Jika $\mathrm{t}_{\text {bitung }}>\mathrm{t}_{\text {tabel }}$ maka $\mathrm{H}_{0}$ ditolak dan $\mathrm{H}_{\mathrm{a}}$ diterima, artinya ada pengaruh model pembelajaran kooperatif tipe STAD dengan bantuan media lingkungan sekitar terhadap hasil belajar IPA siswa kelas V MI Miftahul Ishlah Tembelok.

Berdasarkan pada tabel 1 di atas, dapat disimpulkan bahwa thitung $>t_{\text {tabel }}$ yaitu 3,2250 > 2,0273 pada taraf signifikasi 5\% dengan derajat kebebasan $(\mathrm{dk})=\mathrm{n}_{1}+\mathrm{n}_{2}-2=23+16-$ $2=37$. Hal ini menunjukkan bahwa terdapat pengaruh penerapan model pembelajaran kooperatif tipe student teams achievement division (STAD) dengan bantuan media lingkungan sekitar terhadap hasil belajar IPA siswa kelas V MI Miftahul Ishlah Tembelok tahun pelajaran 2018/2019.

\section{Pembahasan}

Tujuan utama pelaksanaan penelitian ini adalah untuk mengetahui pengaruh dari penerapan model pembelajaran kooperatif tipe student teams achievement division (STAD) dengan bantuan media lingkungan sekitar terhadap hasil belajar IPA siswa kelas V MI Miftahul Ishlah Tembelok tahun pelajaran 2018/2019. Winkel dalam Purwanto mengatakan bahwa hasil belajar adalah perubahan yang mengakibatkan manusia berubah dalam sikap dan tingkah lakunya. Aspek perubahan itu mengacu kepada taksonomi tujuan pengajaran yang dikembangkan oleh Bloom, Simpson, dan Harrow mencakup aspek kognitif, afektif, dan psikomotorik. ${ }^{31}$ Dalam kegiatan pembelajaran atau kegiatan instruksional, biasanya guru menetapkan tujuan belajar. Anak yang berhasil dalam belajar adalah yang berhasil mencapai tujuan-tujuan pembelajaran atau tujuan instruksional. ${ }^{32}$

Secara sederhana, yang dimaksud dengan hasil belajar siswa adalah kemampuan yang diperoleh anak setelah melalui proses kegiatan belajar yang ditunjukkan dalam berbagai bentuk seperti berubah pengetahuannya, pemahamannya, dan keterampilan berpikir. ${ }^{33}$

\footnotetext{
${ }^{31}$ Purwanto, Evaluasi Hasil Belajar ..., hlm. 45.

${ }^{32}$ Ahmad Susanto, Teori Belajar dan pembelajaran ..., hlm. 5.

${ }^{33}$ Ibid.
} 
Tercapainya suatu tujuan pembelajaran yang optimal dalam proses belajar tentunya diharapkan oleh semua guru mata pelajaran termasuk salah satunya dalam pembelajaran IPA.

IPA merupakan rumpun ilmu yang memilki karakteristik khusus yaitu mempelajari fenomena alam yang faktual (factual), baik berupa kenyataan (reality) atau kejadian (events) dan hubungan sebab-akibatnya. ${ }^{34}$ Pembelajaran IPA berhubungan dengan cara berfikir kritis, mencari tahu tentang alam yang sistematis, sehingga mengakibatkan pembelajaran IPA bukan hanya penguasaan kumpulan pengetahuan yang berupa teori dan konsep saja, tetapi juga merupakan suatu proses penemuan. Dengan demikian, proses pembelajaran IPA mengutamakan penelitian dan pemecahan masalah, agar lebih mengembangkan sikap ilmiah siswa yang pada akhirnya dapat meningkatkan hasil belajar mereka.

Student teams achievement division (STAD) merupakan salah satu tipe dari model pembelajaran kooperatif dengan menggunakan kelompok kecil, dimana jumlah anggota dari setiap kelompok terdiri dari 4-5 orang peserta didik secara heterogen. Susanto dalam bukunya mengemukakan bahwa pembelajaran yang efektif adalah pembelajaran yang mampu melibatkan seluruh peserta didik secara aktif. ${ }^{35}$ Pembelajaran dikatakan berhasil dan berkualitas apabila seluruhnya atau sebagian besar peserta didik terlibat secara aktif, baik fisik, mental, maupun sosial dalam proses pembelajaran di samping menunjukkan semangat belajar yang tinggi dan percaya pada diri sendiri. Hal ini dapat dilihat ketika melakukan kegiatan pembelajaran menggunakan model pembelajaran student teams achievement division (STAD) pada kelas eksperimen, peserta didik terlihat sangat antusias dan bergairah ketika dilakukan pembagian kelompok, karena ingin segera mempraktikkan langsung terkait dengan materi perubahan lingkungan yang membahas proses terbentuknya air tanah dan air permukaan.

Penelitian ini mengkolaborasikan model pembelajaran kooperatif tipe STAD dengan bantuan media lingkungan sekitar untuk memudahkan peserta didik memahami mengenai tema lingkungan di sekitar kita pada sub tema perubahan lingkungan yang dapat melibatkan peserta didik secara aktif untuk berpartisipasi dalam kegiatan pembelajaran dengan bantuan

${ }^{34}$ Asih Widi Wisudawati dan Eka Sulistyowati, Metodologi Pembelajaran ..., hlm. 22.

${ }^{35}$ Ahmad Susanto, Teori Belajar dan Pembelajaran ..., hlm. 187. 
media. Sebagaimana yang dikemukakan Nana Sudjana dan Ahmad Rivai bahwa media adalah berbagai jenis komponen dalam lingkungan siswa yang dapat merangsangnya untuk belajar. ${ }^{36}$ Lingkungan sebagai media menyediakan rangsangan (stimulus) terhadap individu dan sebaliknya individu memberikan respon terhadap lingkungan. Dalam proses interaksi itu dapat terjadi perubahan pada diri individu berupa perubahan tingkah laku. Hal ini menunjukkan, bahwa fungsi lingkungan merupakan faktor yang penting dalam proses belajar mengajar. ${ }^{37}$ Lingkungan adalah suatu yang ada di alam sekitar yang memilki makna dan/atau pengaruh tertentu kepada individu. ${ }^{38}$

Adapun media lingkungan sekitar yang dimaksud dalam penelitian ini adalah berupa penggunaan benda-benda seperti botol plastik, batu kerikil, batu-bata, air serta pasir yang dapat mendukung proses pembelajaran dalam melakukan eksperimen atau percobaan mengenai bagaimana terjadinya air tanah dan air permukaan. Dengan demikian akan mampu melibatkan peserta didik secara aktif untuk berpartisipasi dalam kegiatan pembelajaran. Dengan adanya media ini dapat mendukung keberlangsungan proses pembelajaran. Sebagaimana yang telah dilakukan, dengan adanya media peserta didik menjadi lebih aktif dan sebagian besar peserta didik terlibat langsung di dalamya untuk menggunakan sendiri media yang telah ada, dengan semangat dan antusias setiap peserta didik bersama dengan kelompoknya mempraktikkan langsung bagaimana proses terjadinya air tanah dan air permukaan.

Hasil penelitian menunjukkan bahwa ada perbedaan antara nilai $\mathrm{t}_{\text {titung }}$ dengan $\mathrm{t}_{\text {tabel }}$. Nilai rata-rata yang diperoleh kelas eksperimen dan kelas kontrol pada pelaksanaan posttest masing-masing adalah 75,52 dan 63,87. Selain itu, nilai tertinggi untuk kelas eksperimen adalah 93 dan nilai terendahnya adalah 50. Sedangkan pada kelas kontrol nilai tertinggi adalah 87 dan terendahnya 43. Hasil ini menunjukkan adanya perbedaan antara nilai ratarata kelas kontrol dan kelas eksperimen. Perbedaan hasil perolehan nilai pada kelas eksperimen dan kelas kontrol dikarenakan adanya perbedaan pemberian perlakuan (treatment) pada kedua kelas tersebut. Perlakuan yang diberikan pada kelas eksperimen adalah perlakuan khusus, yaitu dengan menerapkan model pembelajaran kooperatif tipe

\footnotetext{
${ }^{36}$ Arief S. Sadiman, dkek.,Media Pendidik.an ..., hlm. 6.

${ }^{37}$ Oemar Hamalik, Proses Belajar Mengajar, (Jakarta: PT Bumi Aksara, 2013), hlm. 194.

${ }^{38}$ Ibid., hlm. 195.
} 
student teams achievement division (STAD) dengan bantuan media lingkungan sekitar, sedangkan pada kelas kontrol hanya dilakukan pembelajaran menggunakan metode ceramah, tanya jawab, penugasan. Pembelajaran model kooperatif tipe STAD dengan bantuan media lingkungan sekitar ini diterapkan karena pembelajaran ini mempunyai peran penting dalam upaya meningkatkan aktivitas belajar peserta didik dan dapat mendongkrak hasil belajar mereka yang masih tergolong rendah khususnya dalam pembelajaran IPA yang terkadang dianggap sangat sulit untuk dipahami.

Ketika diterapkan model pembelajaran kooperatif tipe STAD dengan bantuan media lingkungan sekitar pada kelas eksperimen, peserta didik yang telah dibagi kelompoknya lebih bergairah dan antusias dalam mengikuti proses pembelajaran. Selain itu, peserta didik juga senang ketika mempraktikkan langsung dengan kelompoknya apa yang telah dipelajarai, mereka bekerjasama dalam kelompoknya untuk mencapai tujuan atau hasil yang terbaik dalam kelompoknya masing-masing. Siswa juga lebih antusias karena pembelajaran dikaitkan dengan kehidupan nyata yang dialami siswa dan siswa berpartisipasi secara aktif menggunakan media benda lingkungan sekitar. Dengan demikian, siswa lebih mudah memahami apa yang disampaikan oleh guru mengenai materi perubahan lingkungan terlebih mengenai proses atau penyebab terjadinya air tanah dan air permukaan. Sedangkan pada kelas kontrol, ketika guru menjelaskan mengenai materi perubahan lingkungan menggunakan metode ceramah, tanya jawab, dan penugasan hanya beberapa siswa yang cenderung terlihat memperhatikan dan mengikuti kegiatan pembelajaran secara aktif. Sebagian besar siswa terlihat tidak memperhatikan dan terlihat bosan. Hal inilah yang membuat siswa cenderung kurang memahami apa yang disampaikan oleh gurunya.

Jika dilihat dari kenaikan skor rata-rata hasil belajar pada kelas yang diberikan perlakuan menggunakan STAD dengan bantuan media lingkungan sekitar, maka hal itu sangat sesuai dengan kelebihan yang dipaparkan oleh Jumanta Hamdayama yakni kelebihan model pembelajaran kooperatif, beberapa di antaranya adalah model pembelajaran kooperatif tipe STAD dapat membuat siswa aktif dalam membantu dan memotivasi semangat untuk berhasil bersama, siswa aktif berperan sebagai tutor sebaya untuk lebih meningkatkan keberhasilan kelompoknya, dapat meningkatkan kecakapakan 
individu dan kelompok. ${ }^{39}$ Selain itu, keberadaan media pembelajan sangat membantu proses pembelajaran. Adapun manfaat media di antaranya adalah dapat membantu menarik perhatian dan motivasi siswa untuk belajar, membantu menyajikan materi lebih konkret, mampu menciptakan susasanabelajar yang menyenangkan. ${ }^{40}$

Setelah diketahui adanya perbedaan hasil belajar dari masing-masing kelas, selanjutnya menganalisis data hasil belajar siswa dari kedua kelas. Dalam proses analisis, dilakukan uji normalitas data, uji homogenitas data, dan uji-t. Hasil uji normalitas didapatkan data kedua kelompok berdistribusi normal, yaitu pada kelas eksperimen diperoleh $x^{2}$ hitung $=$ 4,228884 $<x^{2}$ tabel $=5,99$ dan pada kelas kontrol diperoleh $x^{2}$ hitung $=1,060725<$ $x^{2}$ tabel $=5,99$. Sedangkan untuk uji homogenitas didapatkan data kedua kelompok dengan $F_{h i 1}=1,0391812<F_{t}=2,29$, maka didapatkan data kedua kelompok homogen pada taraf signifikansi 5\%.

Setelah kedua persyaratan terpenuhi yaitu kedua kelas tersebut terdistribusi normal dan homogen selanjutnya dilakukan uji hipotesis. Uji hipotesis dianalisis dengan menggunakan rumus $t$-test polled varians. Hasil analisis uji-t dari hasil belajar IPA kedua kelompok yaitu kelas eksperimen dan kelas kontrol dengan pemberian tes berupa soal pilihan ganda, peneliti memperoleh hasil $t_{\text {ht }}=3,22505$ pada taraf signifikansi $5 \%$, harga ini lebih besar dari hasil $t_{t} \quad=2,0275$ yang berarti terdapat perbedaan hasil belajar yang signifikan antara hasil belajar kelas eksperimen yang diajar dengan menggunakan model pembelajarn kooperatif tipe student teams achievement division (STAD) dengan bantuan media lingkungan sekitar dengan kelas kontrol yang diajar hanya menggunakan pembelajaran konvensional (ceramah, tanya jawab, penugasan). Hal ini menunjukkan bahwa $\mathrm{H}_{\mathrm{a}}$ ditolak dan $\mathrm{H}_{\mathrm{a}}$ diterima.

Berdasarkan paparan data dan analisis hasil penelitian. Penelitian ini membuktikan teori yang dikembangkan oleh Robert Slavin tentang model pembelajaran kooperatif tipe student teams achievement division (STAD) bahwa model pembelajaran STAD dengan bantuan media lingkungan sekitar ini dapat meningkatkan hasil belajar IPA siswa kelas V MI Miftahul Ishlah Tembelok tahun pelajaran 2018/2019.

${ }^{39}$ Jumanta Hamdayama, Model dan Metode ..., hlm. 118.

${ }^{40}$ Nunuk Suryani, dkek.,Media Pembelajaran ..., hlm. 14-15. 
Hasil penelitian ini didukung dengan hasil penelitian yang telah dilakukan oleh Sudana dan Wesnawa yang menyatakan bahwa ada peningkatan hasil belajar siswa pada mata pelajaran IPA dengan rata-rata hasil belajar siswa sebesar 88\% setelah penerapan model pembelajaran kooperatif tipe STAD. ${ }^{41}$ Hasil penelitian Adnyasari, dkk. menunjukkan bahwa terdapat pengaruh yang signifikan hasil belajar IPA antara siswa yang mengikuti model pembelajaran kooperatif tipe student teams achievement division (STAD) dengan memanfaatkan lingkungan sebagai sumber belajar dengan siswa yang mengikuti pembelajaran konvensioanal pada siswa kelas V SD. ${ }^{42}$

\section{SIMPULAN DAN SARAN}

\section{Simpulan}

Berdasarkan hasil penelitian, maka dapat disimpulkan bahwa penerapan model pembelajaran kooperatif tipe student teams achievement division (STAD) dengan bantuan media lingkungan sekitar berpengaruh signifikan terhadap hasil belajar IPA siswa kelas V MI Miftahul Ishlah Tembelok tahun pelajaran 2018/2019. Hal ini dapat dilihat dari hasil uji-t, yaitu diperoleh nilai $t_{\text {bitung }}$ sebesar 3,2251, sedangkan nilai $t_{\text {tabel }}$ pada taraf signifikasi $5 \%$ adalah 2,0275, dengan demikian maka $\mathrm{H}_{\mathrm{o}}$ ditolak dan $\mathrm{H}_{\mathrm{a}}$ diterima.

\section{Saran}

Berdasarkan hasil penelitian dan pembahasan di atas disarankan: (1) bagi guru untuk mengembangkan kreativitasnya dalam menerapkan model pembelajaran yang bervariatif yang dapat meningkatkan hasil belajar siswa khususnya pada mata pelajaran IPA tema lingkungan sahabat kita subtema perubahan lingkungan. (2) Bagi sekolah sebaiknya mendorong guru untuk menerapkan berbagai model, serta media pembelajaran, menyediakan fasilitas yang memadai untuk mempermudah guru dalam menerapkan berbagai model pembelajaran demi meningkatnya hasil belajar siswa.

41I Putu Ari Sudana dan I Gede Astra Wesnawa, "Penerapan Model Pembelajaran Kooperatif Tipe STAD Untuk Meningkatkan Hasil Belajar IPA", Jurnal Ilmiah Sekolah Dasar, Vol. 1, Nomor 1, 2017, hlm.6

42I Gst. A. Dian Adnyasari, dkk." Pengaruh Model Pembelajaran Kooperatif Tipe STAD dengan Memanfaatkan Lingkungan Sebagai Sumber Belajar Terhadap Hasil Belajar IPA Siswa SD”.

152 Copyright $\odot$ el-Midad : Jurnal PGMI 2019 


\section{DAFTAR PUSTAKA}

Ahmad Susanto. 2016. Teori Belajar dan Pembelajaran di Sekolah Dasar. Jakarta: Kencana.

Asneli Lubis, 2012. "Pengaruh Model Pembelajatan Kooperatif Tipe STAD Terhadap

Hasil Belajar Fisika Siswa Pada Materi Pokok Gerak Lurus Di Kelas X SMA Swasta UISU Medan", Jurnal Pendidikan Fisika, Vol. 1, Nomor 1, Januari.

Abdul Kadir, Endri Yulianto, dkk., 2014. Dasar-Dasar Pendidikan. Jakarta: Kencana Prenada Media Group.

Arief S. Sadiman, dkk. 2014. Media Pendidikan pengertian, pengembangan, dan pemanfaatannya.

Jakarta: PT Raja Grafindo Persada.

Asih Widi Wisudawati Dan Eka Sulistyowati. 2015. Metodologi Pembelajaran IPA. Jakarta: PT Bumi Aksara.

Bahtiar. 2015. Strategi Belajar Mengajar Sains (IPA). Mataram: Institut Agama Islam Negeri (IAIN) Mataram.

Erwinda Widyanawati. 2016. Keefektifan Model Pembelajaran Learning Cycle 5E

Terhadap Hasil Belajar IPA Materi Perubahan Lingkungan Pada Siswa Kelas IV SD

Gugus Kartini Jepara”, Skripsi, Fakultas Ilmu Pendidikan Universitas Negeri Semarang, Semarang.

Jamaludin, dkk. 2015. Pembelajaran Perspektif Islam. Bandung: Remaja Rosdakarya.

Jumanta Hamdayama, Model dan Metode Pembelajaran Kreatif dan Berkarakter. Bogor: Ghalia Indonesia, 2014.

Muhibbin Syah. 2011. Psikologi Belajar. Jakarta: Bumi Aksara.

Muhammad Nurman. 2015. Evaluasi Pendidikan. Mataram: CV. Sanabil.

Mas'ud. 2012. Penerapan Metode Pembelajaran Talking Stick Untuk Meningkatkan Aktivitas Dan Hasil Belajar IPA Pokok Bahasan Alat-Alat Optiksiswa Kelas V MI Tarbiyatul Mustafid Batu Rimpang Narmada Tahun Pelajaran 2011-2012”, Skripsi, FITK IAIN Mataram, Mataram.

Nana Sudjana dan Ahmad Rivai. 2002. Media Pembelajaran. Bandung: Sinar Baru Algensindo.

Nunuk Suryani, dkk. 2018. Media Pembelajaran Inovatif dan Pengembangannya. Bandung: PT Remaja Rosdakarya. 
Oemar Hamalik. 2013. Proses Belajar Mengajar. Jakarta: PT Bumi Aksara.

Pupuh Fathurrohman dan M. Sobry Sutikno, 2010. Strategi Belajar Mengajar Melalui Penanaman Konsep Umum dan Konsep Islam. Bandung: PT Refika Aditama.

Purwanto. 2014. Evaluasi Hasil Belajar. Yogyakarta: Pustaka Pelajar.

Nasution. 2014. Metode Research Penelitian Ilmiah. Jakarta: PT Bumi Aksara.

Rusman. 2017. Belajar dan Pembelajaran Berorientasi Standar Proses Pendiddikan. Jakarta: Kencana.

Rita Maryana, Ali Nugraha \& Yeni Rachmawati. 2009 Pengelolaan Lingkungan Belajar. Jakarta: Kencana, 2009.

Riduwan. 2015 Dasar-Dasar Statistik. Bandung: Alfabet.

Slameto. 2003. Belajar dan Faktor-Faktor yang Mempengarubinya. Jakarta: Rineka Cipta.

Sumiati Sa'adah. 2004 Sains Untuk Siswa Sekolah Dasar dan Madrasah Ibtidaiyah Kelas 5.

Bandung: Titian Ilmu.

Sumarna Surapranata. 2009. Analisis, Validitas, Reliabilitas, dan Interpretasi Hasil Tes

Implementasi Kurikulum 2013. Bandung: PT Remaja Rosdakarya.

Sugiyono. 2014. Metode Penelitian Kuantitatf Kualitatif dan R\&D. Bandung: Alfabeta.

Sugiyono. 2015. Metode Penelitian pendidikanPendekatan Kuantitatif, Kualitatif, dan R\&D.

Bandung: Alfabeta.

Sri Giarti. 2012. Penerapan Model Pembelajaran Assure Untuk Meningkatkan Hasil Belajar

IPA Siswa Kelas VI SD Negeri 2 Bengle Kecamatan Wonosegero - Boyolali“, Sholaria,

Vol. 2, Nomor 1, Januari.

Trianto. 2009. Mendisain Model Pembelajaran Inovatif-Progresif. Jakarta: Kencana Prenada Media Group.

Trianto Ibnu Badar al-Tabany. 2015. Mendesain Model Pembelajaran Inovatif, Progresif, dan Kontekstual. Jakarta: Prenadamedia Group.

Yusuf. 2015. Strategi Pembelajaran Biologi. Mataram: Institut Agama Islam Negeri (IAIN) Mataram. 